\title{
ФОРМУВАННЯ ТА РОЗВИТОК ІДЕОЛОГІЇ СОБОРНОСТІ НА УКРАЇНСЬКИХ ЗЕМЛЯХ (НАПРИКІНЦІ ХІХ - НА ПОЧАТКУ ХХ СТОЛІтТЯ)
}

\begin{abstract}
У статті характеризується процес формування та розвитку ідеології соборності на українських землях протягом кіния XIX - початку XX століття. Особлива увага приділена визначальним тенденціям розвою ідеології соборності на західноукраӥнських $і$ східноукраӥнських землях. Наголошено, щчо активний розвиток культурно-просвітницького та громадсько-політичного руху на Галичині протягом другоі половини XIX - початку XX століття підготував значне підгрунтя не лише для зміцнення української національної свідомості західних українців, а й-для їх активної участі в національно-визвольних змаганнях періоду 1917-1921 років. Зауважено, щуо протягом тривалого часу в Наддніпрянській Україні та на західноукраӥнських землях поступово формувалися засади ідеологічної концепції, домінуючим чинником котрої були ідеї соборності, самостійності, просвіти народу та духовності.
\end{abstract}

Ключові слова: національна ідеологія, соборниџтво, західноукраӥнські землі, державотворення, східноукраїнські землі, українська нація, ідеї.

Oleksander SYTNYK, Doctor of Historical Sciences, Associate Professor Head of the Department of History, Archeology and Philosophy Melitopol State University named after Bogdan Khmelnitsky

(Ukraine, Melitopol) oleksander_sytnyk@i.ua

\section{FORMATION AND DEVELOPMENT OF THE IDEOLOGY OF CIVILNESS IN UKRAINIAN LANDS (LATE XIX - EARLY XX CENTURY)}

The subject of the study directly concerns the process of the formation and development of ideology of conciliarity in the Ukrainian lands during the late XIX - early XX centuries.

The purpose of the article is to clarify the process of the development of ideology of conciliarity in the Ukrainian lands during the end of the XIX - beginning of the XX century.

The article describes the process of formation and evolution of the ideology of conciliarism in the Ukrainian lands during the end of the XIX - beginning of the XX century. Particular attention is paid to the decisive trends in the development of ideology of conciliarity in Western Ukraine and Eastern Ukraine. It was emphasized that thanks to the efforts of Western Ukrainian and Dnieper leaders, scientists and thinkers, the Ukrainian nation was maturing, which, in particular, led to the emergence of the first Ukrainian parties. The active development of the cultural, educational and socio-political movement in Galicia during the second half of the XIX - early XX centuries was marked. It actually prepared a significant ground not only for strengthening the Ukrainian national consciousness of the Western Ukrainian, but also for their active participation in the national liberation struggle. 1917-1921 years. It has been noticed that for a 
long time the foundations of the ideological concept were gradually formed in the Dnieper Ukraine and in the Western Ukrainian lands, the dominant factor of which were the ideas of unity, independence, enlightenment of the people and spirituality. The development of national ideology, as well as national consciousness, is closely connected with the reproduction of the spiritual memory of the people, which contributes to the conscious and orderly release of dogma from the power and the way to self-knowledge and free spiritual creativity.

The main idea of the article is to assert that for a long time the foundations of the ideological concept were gradually formed in the Dnieper Ukraine and Western Ukraine, the ideas of sobornost, independence, enlightenment of the people and spirituality were the dominant factor. The development of national ideology, as well as national consciousness, is closely connected with the reproduction of the spiritual memory of the people, which contributes to the conscious and orderly release of dogma from the power and the way to self-knowledge and free spiritual creativity.

Thus, it should be summarized that the active development of the cultural, educational and socio-political movement in Galicia during the second half of the XIXth - early XXth centuries prepared a significant ground not only for strengthening the Ukrainian national consciousness of the Western Ukrainian, but also for their active participation in the national liberation competitions of the period 1917-1921. Certain changes were also seen in the development of ideological processes in Western Ukraine, which was manifested, in particular, in the manifestations of their own state, the formation of national identity and the desire for ethnic self-determination.

Key words: national ideology, conciliarity, Western Ukrainian lands, states, Eastern Ukrainian lands, Ukrainian nation, ideas.

Постановка проблеми. Вікове роз'єднання українських земель обумовило не лише бездержавність одним із ключовим аспектом процесу соборності була саме позиція Головна Руська Рада і в подальшому. Загалом друга половина XIX століття ознаменувалася значним підйомом національного руху в Україні. Причому активізація громадсько-політичної діяльності спостерігалася як в Західній, так і в Наддніпрянській Україні. Особливо визначальною була роль Галичини, котра своєрідно відіграла роль українського П’ємонту. У цей період відбувалося визрівання української нації, що проявилося, зокрема, у становленні національного самоусвідомлення та у формуванні національної ідеології. При цьому, протягом другої половини XIX - початку XX століття, попри досить значне поширення різного роду радикальних, марксистських і соціалістичних ідей, ідеологічно переважав постулат політичної самостійності України.

Незважаючи на роз'єднаність західноукраїнських і східноукраїнських земель у зв’язку з їх перебуванням під владою Австро-Угорської та Російської імперій, розвиток ідеологічних напрямків протягом другої половини XIX початку $\mathrm{XX}$ століття відбувався в досить тісному взаємозв'язку та взаємовпливі. Зокрема, ідеологія самостійництва спочатку формувалася в Галичині, але найбільшого піднесення вона досягла в Наддніпрянській Україні. Так М. Міхновський, значною мірою, підсумував фундаментальні 
проблеми національного відродження України, розгорнувши їх в ідеологію незалежності та соборництва України. 3 метою створення основ ідеології національного самовизначення $\mathrm{M}$. Міхновський наприкінці 1898 року намагався реалізувати видавничий проект Русини з початком XX ст., у якому передбачалося задіяти кращі інтелектуальні сили української еліти на обгрунтування історичної та соціальної необхідності й неминучості побудови українським народом соборної незалежної держави як гаранта повноцінного розвитку нації.

Аналіз досліджень. Важливим підгрунтям для цього дослідження стали праці М. С. Грушевського (Грушевський, 2000， 2002， 2007), Д. Донцова (Донцов, 2001), М.П.Драгоманова (Драгоманов, 1991), В. Липинського (Липинський, 2003), М. Міхновського (Міхновський, 1996) та інших. Певним чином процес розвитку української національної ідеології розглядається в роботах О. Багана (Баган, 2013), Я. Дашкевича (Дашкевич, 1991; 1998), В. Кафарського (Кафарський, 1999), І. Лисяка-Рудницького (ЛисякРудницький, 1994), В. П. Ситніка (Ситнік, 2005a, 2005b), П. Соханя (Сохань, 1994), В. Д. Яремчук (Яремчук, 2003) та інших. Однак спеціальне дослідження присвячене формуванню та розвитку ідеології соборності на українських землях протягом періоду з кінця XIX - початку XX століття $€$ відсутнім.

Мета статті полягає в з'ясуванні процесу розвитку ідеології соборності на українських землях протягом кінця XIX - початку XX століття.

Виклад основного матеріалу. Я. Р. Дашкевич зауважив, що українські мислителі творили у новому часі ідеологічні системи, котрі не лише відіграли значну роль у суспільно-політичному житті самої України, але також увійшли до скарбниці ідеологічних надбань наднаціонального діапазону. Такими етапними в історії української ідеології XIX - XX століть стали, по-перше, основоположні документи Кирило-Мефодіївського братства, твори М. Драгоманова, трактати В. Липинського, студії та публіцистика Д. Донцова тощо. Не всі витримали пробу часу. Утопічність наклала відбиток на 
ідеологічні конструкції М. Костомарова й В. Липинського, можливо ще й тому, що ці ідеї ніколи не проходили перевірки в реальності. Сліпе використання ідеологічних схем М. Драгоманова (при якому послідовники не хотіли враховувати еволюцію поглядів самого Драгоманова та результатів, до яких він дійшов під кінець свого шляху) довело до нехтування національним фактором - все ж таки визначальним у національно-визвольній боротьбі - i, в результаті, до різкого гальмування національного руху. Завдяки ідеології Д. Донцова українська нація завдячує вперту й ідейно осмислену - також збройну - боротьбу з гнобителями й в цьому була велетенська заслуга творця саме такої системи політично-суспільних поглядів (Дашкевич, 1998: III). Також слід згадати про величезне значення ідеології М. Міхновського, котра лягла в основу концепції української незалежної держави. У цілому ж, початок формування національно-державницьких ідеологічних концепцій припадає саме на період XIX століття.

Проголосивши своїм кредо космополітизм в ідеях і цілях, національність в грунті й формах культурної праці, він розглядав і українську національну справу через призму загальнолюдських і гуманістичних ідеалів (Сохань, 1994: 8, 9). На думку Я. Дашкевича, дві причини - принципи загальнолюдського космополітичного анархізму й віра в доброго білого демократа (що мала замінити віру в доброго білого царя) - не дали можливості М. Драгоманову дійти до ідеї необхідності утворення незалежної Української держави (теоретично її існування він не виключав). Як учений, Драгоманов прекрасно розумів і довів у своїх наукових працях соборність єдиного українського народу. Але цей народ, навіть піднявшись до найвищих культурних висот, перетворившись на високоорганізовану націю, мав далі залишатися у федеративному зв'язку в межах існуючих у XIX столітті держав - Pociї та Австро-Угорщини (Дашкевич, 1991: 5, 6). Зауваживши всеукраїнський характер драгоманівської програми, I. Лисяк-Рудницький підкреслив, що М. Драгоманов був першим політичним публіцистом й ідеологом, який своїм зором дійсно охоплював цілісність українських земель 
від Кубані до Закарпаття (Лисяк-Рудницький, 1994: 361). Доля закарпатського зраненого брата особливо лежала йому на серці, і їй він присвятив певну увагу в своїх творах (Драгоманов, 1991: 277, 278).

Вже від 1860-х років XIX століття, коли етнографія доповнилася соціальними чинниками, національна самосвідомість українців набула рис національної ідеології на всьому терені від Дону до Карпат, спричинила до змагань нації за політико-правову самовизначеність. I в цьому контексті одною з найбільш соборницьких за суттю стала Молода Україна, котра своєрідно продовжила ідеологію Братства тарасівців. Зокрема відстоювалося право українців на власну націю. При цьому, в основі політичної лінії Молодої України лежали вже не просто прагнення, наміри чи декларативні орієнтири.

Одним із вагомих документів, пов'язаних із Молодою Україною, стала надрукована у Чернівцях М. Міхновським і Б. Грінченком у 1898 році Відозва до Українців в справі заснування українського університету. Автори Відозви... вірно знайшли ключову ланку в низці проблем, які необхідно було вирішити для національного відродження України. Зокрема М. Міхновський починає усвідомлювати необхідність чіткого й послідовного ідейнотеоретичного обгрунтування стратегічної мети та основних завдань національно-визвольного руху, тобто створення ідеології національного відродження. Для реалізації цього задуму наприкінці 1898 року М. Міхновський намагається втілити в життя видавничий проект під назвою Русини 3 початком XX століття. $\mathrm{y}$ цьому проекті $\mathrm{M}$. Міхновський оприлюднив основні ідеї, котрі згодом були розгорнуті ним в ідеологію самостійництва. Згідно з цими ідеями Україна повинна постати вільною, соборною, високорозвиненою нацією, яка посяде належне місце серед розвинених європейських народів; шлях до цієї мети - мобілізація всіх сил нації та самовіддана послідовна політична боротьба, духовною передумовою якої $є$ просвіта народних мас, розвиток національної самосвідомості, консолідація навколо загальнонаціональних інтересів; роль ініціатора, 
організатора і натхненника національно-визвольних змагань повинні взяти на себе патріотично налаштовані кола української інтелігенції (Ситнік, 2005а: 44,48, 51). Обгрунтувавши на конкретному історичному матеріалі неправовий характер політики російського царського уряду щодо України, М. Міхновський проголошує ключове гасло українського самостійницького руху: Одна, єдина, нероздільна, вільна, самостійна Україна від гір Карпатських аж по Кавказькі. Цими словами підкреслювались, щонайменше, три важливих моменти. По-перше, ідея соборності українських земель, що в цей час активно формувалась як у підавстрійській, так і в підросійській Україні. По-друге, власне ідея самостійності України (як способу буття іiі державності). По-третє, етнографічні межі майбутньої самостійної України (Ситнік, 2005b: 110, 111). Серед провідних положень Десяти заповідей УНП виділяються ідеологічні засади, зокрема: Одна, єдина, неподільна від Карпат аж до Кавказу самостійна, вільна, демократична Україна - республіка робочих людей - отсе національний всеукраїнський ідеал. Нехай кожна українська дитина тямить, що вона народилася на світ на те, щоб здійснити цей ідеал гір (Міхновський, 1996: 141, 142).

На рубежі XIX-XX століть національно-соборницький рух різною мірою виявляється в усіх регіонах України. Утверджуючись у Київській, Чернігівській і Полтавській губерніях, він починає охоплювати етнічно змішане чорноморське узбережжя та промисловий Південний Схід. Українському рухові протидіяло існування гібридних форм національної ідентичності на Наддніпрянщині, де не заперечували залишкової української свідомості, але й не творили чіткої та зрозумілої лінії поділу між українцями й росіянами, як у Галичині між українцями й поляками (Лисяк-Рудницький, 1994: 479-482). Тут доречно відзначити, велике значення культурного розвитку в процесі формування національної свідомості українців Галичини. При цьому, значна роль у національному відродженні галицьких українців належала впливам Наддніпрянщини (насамперед завдяки творам 
Т. Шевченка, науково-публіцистичній і громадсько-публіцистичній діяльності М. Грушевського).

У своїй праці Український П’ємонт М. Грушевський писав, що зі зміцненням національного українського руху в Галичині, який від наївного романтизму переходив до вирішення завдань культурного, соціального й політичного розвитку народу, літературна й громадська українська робота, котру проводили в ній місцеві й українські сили Росії, набуває все більшого значення для всіх українських земель. В останнє десятиліття XIX століття Галичина, попри власні вельми тяжкі умови національного й економічного буття, стає центром українського руху, і щодо українських земель Росії відіграє роль культурного арсеналу, де створювались і вдосконалювались засоби національного культурного й політико-суспільного відродження українського народу (Грушевський, 2002: 446). В іншій роботі Галичина і Україна М. Грушевський підкреслює, що в найтяжчі часи українського лихоліття Галичина була світочем національної української культури, народної свідомості і вказувала дорогу українським братам (Грушевський, 2000: 181).

Свого часу В. Антонович через Київську Громаду тримав під своїм впливом взагалі український політичний і культурний рух в межах російської імперії, важливу роль він відігравав і серед галичан, намагаючись вибороти Східній Галичині становище українського П’ємонту - духової батьківщини для цілого українства (Ситник, 2009: 244). Роль М. Грушевського під час його перебування у Львові була, серед іншого, підпорядкована цій меті. Переконливим підтвердженням значної ролі В. Антоновича в процесі координування національно-культурного розвитку Наддніпрянщини та Галичини $\epsilon$ його листування 3 М. Грушевським. Як свідчать листи, В. Антонович покладав велику надію на Галичину як центр тодішнього українського національно-духовного відродження. Шляхом його піднесення й активізації, на думку вченого, слід було розгорнути процес національного відродження і на Східну Україну. Нині ми можемо констатувати, що це був 
воістину пророчий задум. $\mathrm{B.} \mathrm{Антонович} \mathrm{прагнув} 3$ допомогою М. Грушевського піднести громадсько-культурний рух на Галичині на такий рівень, котрий би міг посприяти розвитку національної самосвідомості українців Наддніпрянщини (упор. Ситник: 1991-1992: 396, 397, 404). Завдяки зусиллям західноукраїнських i наддніпрянських діячів, науковців i мислителів, у цей період відбувалося визрівання української нації, що, зокрема, призвело до появи перших українських партій.

Зауваживши ідеологічне роздріблення та розшарування Свропи, В. Липинський, стверджує, що найгіршою небезпекою є універсалістичне думання комуністів, бо воно їм дає сильну внутрішню спайку, однаковий спосіб діяння й реагування. I нема іншого порятунку для європейської цивілізації, як ідеологічній єдності кочівників протиставляти ідеологічну єдність людей осілих в ім'я творчості: матеріалістичному універсалізмові протиставити ідеалістичний універсалізм хліборобів (Липинський, 2003: 19). Аналізуючи проблему єдності українського народу та відштовхуючись від характеру та менталітету українців, В.Липинський вводить поняття хліборобської ідеології, котру він протиставляє комуністичній, буржуазній, міщанській та націоналістичній ідеологіям (Кафарський, 1999: 238). В. Липинський належав до кола нечисленних українських політиків i громадських діячів, які на противагу більшості учасників українського руху в підросійській Україні, що підтримували програму автономії у складі федерації, відстоювали ідею незалежної української держави (Осташко, 2003: 119).

Д. Донцов був фактично перший, хто поставив українське питання на міжнародному рівні. Навіть у праці М. Міхновського Самостійна Україна українська проблема розглядалася як внутрішня проблема Росії. Тому ідея вченого про створення українського коронного краю в межах Австрійської імперії викликала хвилювання не тільки серед росіян, але й серед українців. Його міркування виходили з того, що конфлікти між Росією і Німеччиною та Австрією неминучі, тому українцям потрібно готуватись до нової ситуації 
для того, щоб максимально використати можливості об'єднання українських земель. При цьому, Дмитро Донцов накреслив двоступеневу концепцію визволення України. У творі Підстави нашої політики він, аналізуючи ситуацію, що склалася після Першої світової війни, дійшов висновку, що існує великий конфлікт двох цивілізацій, двох політичних, соціальних i культурно-релігійних ідеалів, конфлікт Європа-Росія. Й особливу роль Донцов відводив Україні, яка стоїть між Росією та Заходом. На думку вченого Україна є плацдармом для наступу Росії на Південь і Захід Свропи до Середземного моря на Близький Схід і до Африки. Тому конфлікт з Росією завжди буде визначати внутрішню і зовнішню політику України. На думку Дмитра Донцова, зовнішня політика має вирішальну роль у боротьбі нації за власну державність. Він доводить, що ні одна нація не визволилася лише власними силами, відтак українська нація повинна шукати порозуміння 3 тими державами, інтереси яких суперечать інтересам Росії на сучасному етапі. Всіляко протидіючи російським впливам на українські землі, Донцов розвиває постулат національної політики, згідно якого в ім'я добра, цілості варто піти на жертву частини, на втрату кількох провінцій: Кожний, хто стремить до з'єднання українських земель зараз, ставлячи цей постулат понад усе і орієнтується на схід - працює на користь Росії, помагаючи їй поставити хрест над українською непідлеглістю. Логічним наслідком першої національної політики - болісна, але певна часова, втрата кількох провінцій. Логічним наслідком противної політики - Росія на наших землях (Донцов, 2001: 109-118, 123-148). Слід відзначити, що ці тези особливо актуальні для нас в умовах сучасної агресії з боку РФ та нагальної потреби консолідації української нації для належного опору загарбнику.

На думку О. Багана, книга Підстави нашої політики була стратегічно важливою ще й в тому плані, що розпочала собою формування правдивого правого, консервативного і націоналістичного руху в Україні і його ідеології. Візія ідеолога точно вловлювала новий ритм історії, нову настроєвість часу, який мав незабаром створити політичний рух цілком нової, відмінної якости, 
якого ще ніколи не було в Україні. Настрій цей визначався як вольовий націоналізм, а його ритміка означала зародження формації, яка вирізнялася особливою жертовністю, принциповістю, героїчністю і дисципліною дій, ОУН. Основний свій удар Д. Донцов спрямував проти ідеології соціалізму в усіх ii варіантах як плебейського, вузькодогматичного i деструктивного способу мислення у політиці, який приніс стільки шкоди українській справі ще від ери М. Драгоманова (друга половина XIX століття). Він викрив i дискредитував усі форми модерного совєтофільства, яке поширювалося в Галичині і на еміграції (позиція М. Грушевського, президента ЗУНР Є. Петрушевича та ін.) і цим великою мірою врятував молоде покоління від дезорієнтації (Баган, 2013: 15, 16). Свою книгу Підстави нашої політики Д. Донцов закінчує тезою про політичну націю як заповіт для українства. На думку Донцова, український народ програв визвольну боротьбу саме через брак державницької ідеології. В цей період Україна не мала своєї ані внутрішньої, ані зовнішньої політики, яка б відповідала українським національним інтересам. Тому, повноцінній нації насамперед потрібна дієва націоналістична, соборницька ідеологія. I саме така парадигма мала б стати основою розвитку сучасної української нації.

На початку 1918 року М. С. Грушевський все більшою мірою підходить до усвідомлення необхідності закріплення самостійності й незалежності Української республіки, досягнення соборності українських земель (Грушевський, 2007: 110, 111). Закликаючи до об’єднання всіх патріотів України, голова Центральної Ради, при цьому, певною мірою, сприяв розвитку державної ідеології, котра б консолідувала націю.

Успіхи українства Наддніпрянщини та державотворчі змагання Центральної Ради надихали громадськість Галичини та Буковини до рішучих дій у напрямі забезпечення українському народові досягнення повної державно-правової самостійності та соборності усієї етнографічної української території. Згодом до цієї ідеї долучилися й інші українські землі - Закарпаття, Холмщина, Підляшшя, Волинь. Однак, на відміну від Великої 
України, де з різною інтенсивністю, але проходив переговорний процес між Центральною Радою та Тимчасовим урядом, де стан революційної демократії, що межував з анархією, дозволяв практично втілювати принципи автономії; в Австро-Угорщині ці процеси фактично блокувалися центральним урядом, а межуючими націями - угорцями в Закарпатті, поляками в Галичині, українцям взагалі відмовлялося не лише в праві на автономію, але й існуванні як окремішньої нації (Яремчук, 2003: 40, 41). Національно-визвольні змагання українського народу піднесли на боротьбу й українців західноукраїнських земель, що перебували під владою АвстроУгорської монархії. Згідно з правом самовизначення націй, проголошеного державами Антанти, 18 жовтня 1918 року Українська парламентська репрезентація скликала у Львові загальні збори політичних і громадських діячів Галичини й Буковини, на котрих було обрано Українську національну раду. Вона мала представляти інтереси українського народу Австрії та Угорщини. 3 усіх частин України в найтяжчому становищі перебувало Закарпаття. Влада Угорщини була для нього тяжким гнітом. Обраний угорським урядом політичний напрямок - мадяризація - нищив українську культуру, економічне життя, будь-які прояви політичної активності. Саме тому представники угорських українців не змогли дістатися на установчі збори, однак надіслали листа, в якому висловлювалась солідарність 3 прагненнями галичан та бажання належати до Української держави.

Висновки. Підсумовуючи слід наголосити, що розвиток ідеї соборності на Наддніпрянській Україні наприкінці XIX - в першій половині XX століття, мав досить складну еволюцію, котру розпочинали українські народникисоціалісти, а завершили ідеологи українського націоналізму.

У роботі Самостійна Україна М. Міхновський, належним чином використавши уроки історичного досвіду боротьби за свою державу, заклав ідеологічні засади подальшої боротьби українських патріотів за незалежність соборної України. Цю тенденцію розвитку ідеї української соборності, 
протягом першої половини XX століття в умовах втрати державності, активно продовжував чільний ідеолог українського націоналізму Дмитро Донцов.

Слід зауважити, що досить тривалий і складний процес самовизначення та самоідентифікації колишніх русинів-руснаків вже як українців, з власною єдиною мовою та національною ідентичністю, відбувався впродовж XIX початку XX століття. Однак, його завершення співпало 3 початком більшовицької окупації українських земель. I саме вона, аналогічно 3 румунською, польською, згодом - угорською окупацією, але значно підступніше й тотальніше знищувала всі паростки самоідентифікації українців.

Таким чином слід підсумувати, що активний розвиток культурнопросвітницького та громадсько-політичного руху на Галичині протягом другої половини XIX - початку XX століття підготував значне підгрунтя не лише для зміцнення української національної свідомості західних українців, а й - для їх активної участі в національно-визвольних змаганнях періоду 19171921 років. Помітними були певні зрушення й у розвитку ідеологічних процесів на західноукраїнських теренах, що проявилося, зокрема, у проявах власного державотворення, формуванні національної ідентичності та прагненні до етнодержавотворчого самовизначення.

Протягом тривалого часу в Наддніпрянській Україні та на західноукраїнських землях поступово формувалися засади ідеологічної концепції, домінуючим чинником котрої були ідеї соборності, самостійності, просвіти народу та духовності. Розвиток національної ідеології, як i національної свідомості тісно пов'язаний із відтворенням духовної пам'яті народу, котра сприяє самоусвідомлюваному й упорядкованому вивільненню 3-під влади догм і виходу на шлях самопізнання й вільної духовної творчості.

\section{СПИСОК ВИКОРИСТАНИХ ДЖЕРЕЛ І ЛІТЕРАТУРИ}

Баган, 2013 - Баган О. Стратегія для України: через героїчну націософію до наступальної геополітики (1921 - 1932 рр.). Передмова // Донцов Д. Вибрані твори: у 10 т. / Упоряд., післям., комент. О. Баган. Дрогобич, 2013. Т. 5: Політична аналітика (1921 - 1932 рр.). С. 5-16. 
Грушевський, 2007 - Грушевський М. С. В огні й бурію. Львів, 2007. С. 110, 111. (Твори: У 50 т.; Т. 4. Кн. 1: Серія Суспільно-політичні твори (доба Української Центральної Ради)).

Грушевський, 2000 - Грушевський М. С. Галичина і Україна // Націоналізм: Антологія; упоряд. О. Проценко, В. Лісовий. К.: Смолоскип, 2000. С. 180-187.

Грушевський, 2002 - Грушевський М. С. Український П'ємонт // Грушевський М. С. Твори : у 50 т. / редкол.: П. Сохань, Я. Дашкевич, І. Гирич та ін.; голов. ред. П. Сохань. Львів, 2002. Т. 1: Серія Суспільнополітичні твори (1894 - 1907). С. 444-447.

Дашкевич, 1998 - Дашкевич Я. Україна у вогні ідеологій // Кісь Р. Фінал Третього Риму (Російська ідея на зламі тисячоліть). Львів, 1998. С. I-XIV.

Дашкевич, 1991 - Дашкевич Я. Учений, політик, публіцист // Слово і час. 1991. № 10. С. 3-6.

Донцов, 2001 - Донцов Д. Підстави нашої політики // Донцов Д. Твори. Львів, 2001. Т. 1: Геополітичні та ідеологічні праці. С. 91-242.

Драгоманов, 1991 - Драгоманов М. П. Вибране (...мій задум зложити очерк історії цивілізації на Україні). К., 1991. 688 с.

Кафарський, 1991 - Кафарський В. Нація і держава: Культура. Ідеологія. Духовність. Івано-Франківськ, $1999.336 \mathrm{c.}$

Липинський, 2003 - Липинський В. Універсалізм у хліборобській ідеології; за ред. Я. Пеленського, Р. Залуцького, Х. Пеленської та ін. // Листування В. Липинського Т. 1. К., 2003. С. 13-19.

Ситник, 1991 - 1992 - Листи В. Антоновича до М. Грушевського; упор. О. М. Ситник // Український історик. 1991 - 1992. Т. 28-29. Ч. 3-4; 1-4. С. 396-411.

Лисяк-Рудницький, 1994 - Лисяк-Рудницький І. Історичні есе: у 2 т.; пер. 3 англ. М. Бідак, У. Гавришків, Я. Грицака, А. Дещиці, Г. Киван, Е. Панкеєвої. К., 1994. Т. 1. 554 с.

Міхновський, 1996 - Міхновський М. Х заповідей УНП // Політологія. Кінець ХІХ - перша пол. ХХ ст.: хрестоматія. Л., 1996. С. 141-142.

Осташко, 2003 - Осташко Т. Суспільно-політична діяльність В'ячеслава Липинського на тлі його листування // Листування В. Липинського; за ред. Я. Пеленського, Р. Залуцького, Х. Пеленської та ін. Т. 1. К.: Смолоскип, 2003. С. 119-152.

Ситник, 2009 - Ситник О. М. Формування та еволюція ідеологічних концепцій національно-державницького спрямування в Україні (від початку ХІХ ст. - до 1939 р.): монографія. Донецьк, 2009. 549 с.

Ситнік, 2005a - Ситнік В. Громадсько-політична діяльність М. Міхновського: дис.... кандидата іст. наук: 07.00.01. K., 2005. $208 \mathrm{c}$.

Ситнік, 2005b - Ситнік В. Самостійна Україна М. Міхновського - видатна пам'ятка української націоналістичної думки // Визвольний шлях. 2005. Кн 2. С. 106-113.

Сохань, 1994 - Сохань П. Б. Д. Грінченко - М. П. Драгоманов: Діалоги про українську національну справу // Джерела з історії суспільно-політичного руху в Україні ХІХ - початку ХХ ст. Вип. І. К., 1994. С. 5-17.

Яремчук, 2003 - Яремчук В.Д. Вплив державотворення в Наддніпрянській Україні на розвиток національно-визвольного руху у західноукраїнських землях // Украӥнський історичний журнал. 2003 . № 4. C. $38-45$.

\section{REFERENCES}

Bagan, 2013 - Bagan O. Strateghija dlja Ukrajiny: cherez gherojichnu naciosofiju do nastupaljnoji gheopolityky (1921 - 1932 rr.). Peredmova. [Ukraine: A strategy for Ukraine: through heroic nationalosophia to offensive geopolitics (1921 - 1932 biennium). Preface] // Dontsov D. Selected Works: 10 t./Sim., Aftermath, Comment. O. Bahan. Drohobych, 2013. T. 5: Political analytics (1921 - 1932 biennium). P. 5-16 [in Ukrainian].

Grushevsky, 2007 - Grushevsky M. S. V oghni j buriju. [Ukraine: In the fire and the storm]. Lviv, 2007. P. $110,111$. (Works: In 50 t., T. 4. Book 1: Series Socio-political works (the time of the Ukrainian Central Rada) [in Ukrainian].

Hrushevsky, 2000 - Hrushevsky M. S. Ghalychyna i Ukrajina. [Ukraine: Galicia and Ukraine] // Nationalism: Anthology; arrangement of O. Protsenko, V. Forest. K., 2000. P. 180-187 [in Ukrainian].

Hrushevsky, 2002 - Hrushevsky M. S. Ukrajinsjkyj P'jemont. [Ukraine: Ukrainian Pieemont] // Hrushevsky M. S. Works: 50 tons / ed.: P. Sokhan, Ya. Dashkevich, I. Girich and others; heads edit P. Sokhan Lviv, 2002. T. 1: Series Socio-Political Works (1894 - 1907). P. 444-447 [in Ukrainian].

Dashkevich, 1998 - Dashkevich Ya. Ukrajina u voghni ideologhij. [Ukraine: Ukraine in the Light of Ideologies] // Kis R. The Final of Third Rome (Russian Idea on the Millennium). Lviv, 1998. P. I-XIV [in Ukrainian].

Dashkevich, 1991 - Dashkevich Ya. Uchenyj, polityk, publicyst. [Ukraine: Scientist, politician, publicist] // Word and time. 1991. No. 10. P. 3-6 [in Ukrainian].

Dontsov, 2001 - Dontsov D. Pidstavy nashoji polityky. [Ukraine: The Foundations of Our Policy] // Dontsov D. Works. Lviv, 2001. T. 1: Geopolitical and ideological works. P. 91-242 [in Ukrainian].

Drahomanov, 1991 - Drahomanov M. P. Vybrane (...mij zadum zlozhyty ocherk istoriji cyvilizaciji na Ukrajini). [Ukraine: Vybrana (... my intention is to reproduce the essay on the history of civilization in Ukraine)]. K., 1991. 688 p. [in Ukrainian]. 
Kafarsky, 1991 - Kafarsky V. Nacija i derzhava: Kuljtura. Ideologhija. Dukhovnistj. [Ukraine: Nation and state: Culture. Ideology. Spirituality]. Ivano-Frankivsk, 1999. 336 p. [in Ukrainian].

Lipinsky, 2003 - Lipinsky B. Universalizm u khliborobsjkij ideologhiji. [Ukraine: Universalism in the agricultural ideology]; ed. J. Pelensky, R. Zalutsky, H. Pelenskaya and others // Listing V. Lypynsky T. 1. K., 2003. P. 13-19 [in Ukrainian].

Sytnyk, 1991 - 1992 - Sytnyk O. Lysty V. Antonovycha do M. Ghrushevsjkogho. [Ukraine: Letters of Antonovich to M. Hrushevsky]; emphasis O. M. Sytnyk // Ukrainian Historian. 1991 - 1992. T. 28-29. Ch. 3-4; 1-4. P. 396-411 [in Ukrainian].

Lysiak-Rudnytsky, 1994 - Lysiak-Rudnytsky I. Istorychni ese: u 2 t. [Ukraine: Historical essays: 2 t.]; per. from english M. Bedak, V. Gavrishkov, Y. Hrytsak, A. Deshchits, G. Kivan, E. Pankeeva. K., 1994. T. 1. 554 p. [in Ukrainian].

Mikhnovsky, 1996 - Mikhnovsky M. X zapovidej UNP. [Ukraine: The X Commandments of the UNP] // Politics. The end of the XIXth - the first floor. XX centuries: the textbook. L., 1996. P. 141-142 [in Ukrainian].

Ostashko, 2003 - Ostashko T. Suspiljno-politychna dijaljnistj V'jacheslava Lypynsjkogho na tli jogho lystuvannja. [Ukraine: Social-political activity of Vyacheslav Lipinsky with the background of his correspondence] // Correspondence of V. Lypynsky; ed. J. Pelensky, R. Zalutsky, H. Pelenskaya and others. T. 1. K., 2003. P. 119-152 [in Ukrainian].

Sytnyk, 2009 - Sytnyk O. M. Formuvannja ta evoljucija ideologhichnykh koncepcij nacionaljno-derzhavnycjkogho sprjamuvannja v Ukrajini (vid pochatku KhIKh st. - do 1939 r.): monoghrafija. [Ukraine: Formation and evolution of ideological concepts of national-state orientation in Ukraine (from the beginning of the nineteenth century to 1939): monograph]. Donetsk, 2009. 549 p. [in Ukrainian].

Sytnik, 2005a - Sytnik V. Ghromadsjko-politychna dijaljnistj M. Mikhnovsjkogho: dys.... kandydata ist. nauk: 07.00.01. [Ukraine: Public-political activity of M. Mikhnovsky: dis .... candidate right Sciences: 07.00.01]. K., 2005. 208 p. [in Ukrainian].

Sytnik, 2005b - Sytnik V. Samostijna Ukrajina M. Mikhnovsjkogho - vydatna pam'jatka ukrajinsjkoji nacionalistychnoji dumky. [Ukraine: Independent Ukraine by M. Mikhnovsky - an outstanding monument of Ukrainian nationalistic thought] // Liberation Road. 2005. Book 2. P. 106-113 [in Ukrainian].

Sokhan, 1994 - Sokhan P. B. B. D. Ghrinchenko - M. P. Draghomanov: Dialoghy pro ukrajinsjku nacionaljnu spravu. [Ukraine: D. Grinchenko - M.P. Drahomanov: Dialogues on the Ukrainian national affair] // Sources on the history of the social and political movement in Ukraine from the nineteenth and early twentieth centuries. T. I. K., 1994. P. 5-17 [in Ukrainian].

Yaremchuk, 2003 - Yaremchuk V. D. Vplyv derzhavotvorennja v Naddniprjansjkij Ukrajini na rozvytok nacionaljno-vyzvoljnogho rukhu u zakhidnoukrajinsjkykh zemljakh. [Ukraine: The Influence of State Development in the Dnieper Ukraine on the Development of the National Liberation Movement in Western Ukraine] // Ukrainian Historical Magazine. 2003. No. 4. P. 38-45 [in Ukrainian]. 